\title{
ODNOS MENADŽMENTA PREDUZEĆA I KORPORATIVNOG UPRAVLJANJA
}

\begin{abstract}
Rezime:
Razvoj složenijih oblika organizovanja preduzeća uslovio je stvaranje manjeg broja ekonomski složenijih, ali $\mathrm{i}$ organizaciono kompleksnijih i komlikovanijih korporativnih organizacija za čije uspešno vođenje vlasnici često nisu imali dovoljno potencijala pa su angažovali profesionalne i kompetentne timove stručnjaka kojima su poveravali upravljanje takvim organizacijama. Ostvarujući moć novim idejama i konceptima zasnovanim na znanju, menadzeri u korporacijama postaju nezamenjiv element moći svakog preduzeća da se izmeni, prilagodi i stvori nove mogućnosti da se uspešno takmiči u veoma promenljivom poslovnom okruženju. Međutim, prebacivanje odgovornosti za upravljanje korporacijom na menadžere ima za posledicu i pojavu zloupotrebe rukovodeće pozicije radi realizacije sopstvenih interesa. Osnovni cilj ovog rada je da ukaže kako za razliku od klasičnih preduzeća, danas imamo situaciju u kojoj se kao svojina vlasnika korporacija predstavlja idejno i misaono rešenje menadžera što bi trebalo da predstavlja wihovu intelektualnu svojinu.
\end{abstract}

Ključne reči: korporativno upravljanje, menadžemnt proces, intelektualna svojina, preduzeće.

\section{UVOD}

Prema definiciji iz Leksikona menadžmenta (Đorđević, i dr. 2006), korporacija je najrazvijeniji oblik kapitalističkog preduzeća. Jedan je od pravnih oblika trgovačkih društava i ima brojne prednosti u odnosu na druge pravne oblike trgovačkih društava. Korporacija je uspela otkloniti sve slabosti ortačkih društava, posebno one koje se odnose na rizik, budući da u slučaju bankrota korporacije, vlasnik akcija gubi samo ono što je uložio u akcije.

Korporacija kao društvo kapitala, do sredstava za osnivanje i poslovanje dolazi izdavanjem akcija. Novčani iznos potreban za osnivanje i rad korporacije zove se osnovna glavnica, koja se deli na određeni broj akcija. Akcije se nalaze u rukama akcionara, vlasnika korporacije. Korporacije se najčešće osnivaju kao akcionarska društva. U gigantskim korporacijama broj akcionara raste na stotine hiljada pa, u nekim slučajevima, i više od miliona. Korporacija je jedan od najsavršenijih načina prikupljanja kapitala, posebno u onim delatnostima u kojima priroda procesa proizvodnje zahteva veliki novac. Korporacije imaju složenu organizacijsku strukturu, s većim brojem preduzeća (kćerki) u svom sastavu.

Osnovni kriterijum upravljanja korporacijskim preduzećima u njenom sastavu je većinsko vlasništvo nad akcijama tih preduzeća. Velike korporacije, s obzirom na složenost svoje strukture, pristupaju procesima divizionalizacije organizacijske strukture i decentralizacije rukovođenja, te formiranju relativno autonomnih jedinica po delatnostima, profitnim centrima i strateškim poslovnim jedinicama, kako bi izbegli njihovu veliku tromost i potsticali prilagođavanje zahtevima okoline u kojoj deluju. Korporacije imaju, posebno one najveće, na stotine pa i više lokalnih kompanija, širom sveta. Sve se te lokalne kompanije objedinjavaju u manji ili veći broj poslovnih područja, odnosno programa. Jedno poslovno područje odnosno program može objediniti veći broj preduzeća iz različitih zemalja koje po srodnosti spadaju u određeno poslovno područje. Najčešći oblici korporativne saradnje, povezivanja i udruživanja u savremenoj tržišnoj privredi su: karteli, koncerni, trustovi, konglomerati i multinacionalne kompanije (Jovičić i Mirosavljević, 2012).

U korporacijama se sve više razvija unutrašnje preduzetništvo (intrapreduzetništvo) odnosno proces formiranja malih, relativno autonomnih preduzeća, odnosno jedinica u okviru korporacije kojima se dodeljuju potrebna sredstva, ljudi i organizacijska samostalnost da bi svi pojedinci koji imaju preduzetničke ideje, talenat i sposobnost, mogli realizovati te svoje ideje, otvaranjem novih firmi u okvirima postojećeg preduzeća. Na taj način korporacija može sačuvati najtalentovanije i najkreativnije ljude, a takođe može i ravnopravno konkurisati u pogledu preduzetništva i inovativnosti malih preduzetničkih firmi. Korporacije imaju i svoje slabosti. U samoj osnovi korporacije nalazi se konflikt između onih koji snose rizik (akcionara) i onih koji tim rizikom upravljaju (menadžera). Korporacije čine veoma mali procenat od ukupnog broja preduzeća u privredi neke zemlje, ali po svom ekonomskom potencijalu, proizvodnji i broju zaposlenih one su nosioci privrede svake razvijene zemlje.

\footnotetext{
${ }^{1}$ Vojna akademija, Univerzitet odbrane, Beograd, milan.mih83@gmail.com
} 
Ideja o kreiranju poslovne politike, kao i sam misaoni proces predstavlja intelektualnu tvorevinu menadžera u savremenim preduzećima. Upravo zbog navedenog, cilj ovog rada je da ukaže na potrebu da korporacije traže modalitete u upravljačkoj strukturi, koji bi mogli pomoći ne samo da se preduzeća orijentišu ka tržištu, već da takvu orijentaciju iskoriste kao način za ostvarivanje dugoročno održive konkurentske prednosti. Intelektualni kapital je ključni faktor za proizvođenje konkurentskih prednosti kompanija - jer konkurentska prednost zasnovana na intelektualnom kapitalu omogućava stvaranje veće dodate vrednosti proizvodima i uslugama, a na taj način i dugoročni rast te organizacije.

U ovom radu ćemo prikazati ulogu korporativnog upravljanja menadžmenta i njegov odnos sa vlasnicima. Imajući u vidu, kada se govori o intelektualnom kapitalu i funkciji menadzmenta, da se radi o ključnim resursima savremenih preduzeća od posebne je važnosti za čitaoce ovog rada koji se bave izučavanjem ove problematike da uoče značaj kreiranja i implementacije adekvatnog sistema upravljanja (menadzmenta) za produktivno korišćenje intelektualne svojine radi ostvarivanja rasta i razvoja.

\section{SPECIFIČNOSTI KORPORATIVNOG UPRAVLJANJA}

U poslednjih nekoliko godina termin korporativno upravljanje se veoma često koristi. Postavlja se pitanje da li imamo dovoljno saznanja o tome šta je to i kakve posledice ima ili bi trebalo da ima za preduzeće. Različiti su pristupi i različito definisanje pojma korporativnog upravljanja.

Korporativno upravljanje predstavlja odnos između menadžmenta preduzeća odnosno uprave i onih koji imaju svoj udeo vlasništva u tom preduzeću odnosno akcionara (Babić, 2004). Ovo ukazuje na obaveze onih koji u ime i za račun vlasnika kapitala upravljaju tim kapitalom, tj. uprave, da ostvare projektovane zadatke, odnosno ciljeve i da, u isto vreme, obezbede poslovanje u skladu sa pozitivnim zakonskim propisima kao i apsolutnu javnost rada.

$\mathrm{U}$ isto vreme, od kvaliteta rada menadžmenta preduzeća zavisi veća ili manja zainteresovanost budućih investitora za ulaganje, odnosno za kupovinu akcija, ili se postiže veća ili manja cena preduzeća na berzi. Prema ovome, uspostavljaju se prava i obaveze menadžera preduzeća i u vidu zahteva vlasnika kapitala.

Korporativno upravljanje se definiše i kao sistem kojim se kompanije kontrolišu i usmeravaju. Pri tome, polazi se od činjenice da postoje vlasnici kapitala koji su izuzetno zainteresovani za poslovanje firme i to kroz ostvarenje rezultata u vidu profita koji će se usmeriti bilo na dividende akcionara bilo na razvoj preduzeća. Kao posledica te želje akcionara postavlja se, odnosno bira se uprava i nadzor koji su direktno postavljeni i direktno kontrolisani od strane vlasnika kapitala. To su najčešće upravni i nadzorni odbori sa različitom kvalifikacionom, stručnom, motivacionom, polnom i drugom strukturom u zavisnosti od karaktera preduzeća. Iz ovoga možemo zaključiti da je proces korporativnog upravljanja rezultat intelektualnog napora menadžmenta.

Struktura korporativnog upravljanja podrazumeva skupštinu akcionara, upravni odbor i nadzorni odbor. Pored ova tri temeljna upravljačka tela, u korporacijama se formiraju i drugi organi kao što su odbor za reviziju, interna kontrola i dr.

Nakon realizacije definisanih ciljeva, vrši se poređenje ostvarenja sa definisanim standardima i, ako je došlo do odstupanja ostvarenja od standarda izvan zone tolerancije, pristupa se korekciji sopstvenog ponašanja. Ovo je neophodno jer, otklanjanjem grešaka koje su uočene, sprečava se entropija sistema ili stanje njegove najveće ravnoteže, odnosno stanje haosa. Svi ovi procesi moraju biti integrisani da bi se postigao sinergetski efekat od koristi za samo preduzeće.

$\mathrm{Na}$ osnovu svega navedenog proizilazi da je korporativno upravljanje strukutra vođenja i nadziranja nekog akcionarskog društva. $U$ najširem obliku, to predstavlja odnos između uprave i zaposlenih, odnosno institucija koje su investirale u korporaciju da bi se ostvarila dobit. Ovo nas upućuje da se korporativno upravljanje odnosi na relacije menadžmenta i vlasnika.

Praksa dobrog korporativnog upravljanja, koja štiti interese, pre svega, manjinskih akcionara od odlučujućeg je značaja za privlačenje direktnih stranih investicija u svakoj zemlji. Efikasnost rada menadžmenta u korporaciji povećava se doživotnim učenjem i vežbanjem ključnih postupaka kod donošenja odluka i podsticanja njihove realizacije, kao i kontrole izvršenja.(Sofronijević, i dr 2013)

\section{STANDARDI I PRINCIPI KORPORATIVNOG UPRAVLJANJA}

Veoma je bitno utvrditi standarde korporativnog upravljanja koji nisu ništa drugo do definisani nivoi kvaliteta i kvantita, koji služe za upoređivanje sa ostvarenjima. U nekim zemljama ti standardi imaju i karakter zakona, kao što je slučaj sa SAD, gde se primenjuje Sarbanes-Oxley zakon.

Potreba za donošenjem standarda proistekla je iz težnje da se eliminišu greške kojima su najčešće skloni ljudi koji vode preduzeće. Te greške mogu biti sledeće:

- loš menadžment;

- slaba ili nedovoljna komunikacija;

- arogancija menadžmenta; 
- nerealno visoka plata menadžera;

- nekompetentnost vodećih ljudi;

- želja za liderskom moći;

- korumpiranost i

- generalno, loše ponašanje zaposlenih i menadžera.

Definisanjem standarda ove negativnosti se pokušavaju eliminisati ili pak svesti u zonu tolerancije. Standardima upravljanja detaljno se utvrđuju načini funkcionisanja, kao i načini zaštite interesa svih stejkholdera, odnosno svih nosilaca interesa u akcionarskim društvima. Ti standardi se, mogu posmatrati kao:

- pravo na upravljanje akcionarskim društvima;

- pravo na pravovremeno i redovno dobijanje relevantnih informacija o akcionarskim društvima;

- pravo na deo dobiti akcionarskog društva;

- pravo na prenos akcija:

- pravo na sigurnu i brzu registraciju vlasništva;

- pravo akcionara da biraju i budu birani u upravni odbor;

- pravo na deo kapitala iz likvidacione mase;

- ravnopravan tretman svih akcionara;

- uloga zainteresovanih strana u upravljanju akcionarskim društvima;

- objavljivanje i javnost informacija;

- uloga i odgovornost odbora (uprava društva, nadzorni odbor, sukob interesa-odbor za reviziju).

Ovi standardi su, u suštini, proistekli iz opšteprihvaćenih principa korporativnog upravljanja, prihvaćenih od strane Organizacije za ekonomsku saradnju i razvoj (OECD-a).

U principu, suština korporativnog upravljanja svodi se na to: Kako obezbediti da menadžeriprofesionalci rade u korist preduzeća i vlasnika, a ne samo u sopstvenu korist (Mihajlović i Dašić, 2009). Sigurno je da menadžeri imaju svoje interese koji se, pre svega, ispoljavaju u materijalnoj naknadi za njihovo angažovanje, kao i neke druge povlastice koje žele sa tog mesta da pribave za sebe. Logično je da imaju svoje interese i logično je da ti interesi globalno budu usaglašeni sa interesima vlasnika kapitala. Idealno je da se ti interesi međusobno podudaraju. I ne samo interesi menadžera nego i interesi svih stejkholdera.

Problem se može javiti kada je broj vlasnika preduzeća izuzetno veliki i kada nijedan od njih nema ni interesa, a ni snage da u potpunosti kontroliše menadžere. Tada su menadžeri, najčešće, u situaciji da rade u svoju korist, a na štetu vlasnika, jer ne postoji efikasan mehanizam njihove kontrole, odnosno sankcionisanja, kao što je, eventualno, smenjivanje.

Vrlo efikasan način kontrolisanja rada i ponašanja menadžera postiže se i regulisanjem pravnog statusa menadžmenta i ovde se ističe samo nekoliko bitnih aspekata tog regulisanja onako kako je to definisala anglosaksonska pravna škola.

Prvo i osnovno pravilo je apsolutna posvećenost poslu koji se obavlja. Zatim slede principi kao što su: da nije dozvoljeno da se eventualna šansa koja se ukaže preduzeću okrene u sopstvenu korist; interes menadžera mora biti javan i ne sme postojati nikakav kolateralan cilj za koji se ne zna, objektivno su privilegovani u delu raspolaganja određenim informacijama.

Jedan od razloga veoma malog prisustva direktnih investicija u Srbiji, i pored vrlo izraženog deklarativnog pozivanja za ulaganjima, jeste nedostatak kvalitetnog korporativnog upravljanja.

$\mathrm{Na}$ osnovu prethodnog, korporativno upravljanje je vrlo složen proces $\mathrm{i}$, u principu, imanentan svim privrednim društvima. U principu, ono podrazumeva odnose u okviru stejkholdera, sa posebnim osvrtom na odnose vlasnika i onih koji u njihovo ime i za njihov račun upravljaju njihovim kapitalom. $\mathrm{Na}$ jednoj strani imamo vlasnike-akcionare sa svojim zahtevima i ciljevima koje žele da ostvare i da u čitavom procesu ostvarenja tih ciljeva imaju kontrolu i znatan deo uticaja na sam tok procesa, a na drugoj strani menadžere koji svoje ciljeve vide, pre svega, u materijalnoj nadoknadi za angažovanje kao i potrebi gradnje karijere. Zato akcionari formiraju Skupštinu akcionara koja bira upravni odbor da upravlja preduzećem. Upravni odbor bira upravu koja ima upravljačko-rukovodnu ili izvršno-upravljačku funkciju. Nadzorni odbor ima ulogu da nadzire, tj. kontroliše rad, pre svega, uprave i to najčešće u delu poštovanja zakonitosti i javnosti u radu.

Bez obzira na moguće modalitete, cilj korporativnog upravljanja je dostizanje takvog nivoa poslovanja preduzeća kojim će se uspešno ostvarivati ciljevi i zadovoljavati interesi svih stejkholedra a, pre svega, vlasnika kapitala i menadžera.

U ovom aspektu posmatrawa možemo zaključiti da se nadoknada za rad menadžera često poistovećuje sa nadoknadom za kupovinu određene licence, ali se u ovom slučaju to formalno ne dovodi u ravnotežu. 


\section{CILJ KORPORATIVNOG PREDUZEČA}

Prema teorijskim stavovima često su podeljena mišljenja oko osnovnog cilja korporativnog preduzeća. Jedna grupa autora se zalaže za činjenicu, da je cilj korporativnog preduzeća maksimiranje profita. Za realizaciju ovog cilja se naglašava značaj intelktualnog kapitala. „U današnjem poslovanju imamo situaciji u kojoj je intelektualni kapital preuzeo ulogu ključnog lidera, kada sa sigurnošću možemo reći da vrednost neke organizacije više od $50 \%$ čini vrednost intelektualnog kapitala. Obzirom da govorimo o većinskoj vrednosti organizacije nameće se pitanje, da li taj ključni element ima svoju strategiju i kakva je njena uloga u poslovnoj strategiji jedne organizacije?"(Miletić i dr. 2014)

Druga grupa autora polazi od pretpostavke da je cilj korporativnog preduzeća dobit po emitovanim akcijama. Za maksimiranje ukupnog profita preduzeća se ne može reći da je osnovni cilj korporativnog preduzeća, jer je manje sveobuhvatan u odnosu na ostvarenu dobit po emitovanim akcijama. Ova tvrdnja se potrkrepljuje činjenicom, da korporativna preduzeća u uslovima nedostatka profita, mogu emitovati nove akcije $\mathrm{i}$ iskoristiti dotične prihode za investiranje u državne obveznice. Na ovaj način se relativno lako može doći do povećanja ukupnog profita, a da je isti direktni produkt umešnosti vođenja finansijske i poslovne politike od strane njenog menadžmenta. $U$ tom smislu sasvim je zaočekivati da se model emisije i uslovi emitovanja akcija posmatraju kao intelektualna svojina menadžera. Treba istaći, da ni maksimiranje dobiti po emitovanim akcijama ne može predstavljati sasvim prikladan cilj korporativnog preduzeća. Naime, prihod po emitovanim akcijama ograničen je sa dva faktora (Jovičić i Stavrić, 2009):

- vremenskim rasporedom (vremenskom distancom) očekivanog povrata, i

- rizikom (neizvesnošću) očekivane dobiti.

Treća grupa autora polazi od činjenice, da je osnovni cilj svakog korporativnog preduzeća da stvori vrednost svojim akcionarima. Vrednost akcije se iskazuje putem tržišne cene obične (redovne) akcije u korporativnom preduzeću. Stoga se može izvesti zaključak, da je osnovni cilj korporativnog preduzeća tržišna cena njegove akcije. Vrednost akcije zavisi od odluke preduzeća: da li će se opredeliti: a) za dugoročno investiranje, b) za kratkoročno finansiranje ili c) za dividendu. Ukoliko je pristuna optimalna kombinacija sve tri odluke, tada se može sa izvesnom sigurnošću tvrditi, da će akcionarima porasti vrednost njihovog preduzeća.

\section{UPRAVLJANJE KORPORATIVNIM PREDUZEČEM}

U onoj meri u kojoj su vlasnici običnih (redovnih) akcija i vlasnici korporativnog preduzeća, zavisi i njihovo pravo da biraju upravni odbor, a putem njega i poslovodstvo koje kontroliše poslovanje tog preduzeća. Kod manjih korporativnih preduzeća dato je direktno pravo vlasnicima da upravljaju preduzećem. U zavisnosti od organizacije korporacije, upravni odbor (broj direktora) se može birati većinskim ili kumulativnim glasačkim sastavom. Ukoliko je prisutan većinski glasački sastav, tada akcionari imaju jedan glas za svaku akciju koju poseduju i u obavezi su da glasaju za svaki direktorski položaj koji je otvoren.

Kod kumulativnog načina glasanja, akcionar ima mogućnost da kumulira glasove i da ih poveri manjem broju direktora koji se biraju. Kumulativnim načinom glasanja stvara se mogućnost (za razliku od većinskog načina glasanja) da i manja interesna grupa akcionara utiče na izbor određenog broja direktora (članova upravnog odbora).

Upravljanje korporativnim preduzećem podrazumeva direktno učešće akcionara na godišnjoj skupštini korporativnog preduzeća, odnosno putem punomoći za zastupanje akcionara. Potpisivanjem punomoći akcionar prepušta svoje glasačko pravo nekoj drugoj osobi. Pri tome reguliše način zastupanja, kao i zahtev od korporativnog preduzeća da obaveštava akcionare putem zastupničke pošte. Obaveza je poslovodstva korporacije da pre godišnje skupštine prikupi potvrde o zastupanju od akcionara, kako bi se glasalo za predloženu listu direktora, ili za neki drugi predlog koji zavisi od akcionara. Prisutni su u praksi slučajevi, gde se punomoć akcionara može dati osobama koje nisu u poslovodstvu korporacije, te se tako može uspostaviti spoljna kontrola upravljanja korporacijom.

Korporativno upravljanje je jedan od ključnih elemenata u poboljšavanju ekonomske efikasnosti i rasta, kao i u povećavanju poverenja investitora. Korporativno upravljanje obuhvata skup odnosa između menadžmenta kompanije, njenog upravnog odbora, njenih akcionara i ostalih stejkholdera. Korporativno upravljanje takođe pruža strukturu u kojoj se postavljaju ciljevi kompanije i određuju sredstva za ostvarivanje tih ciljeva i praćenje performansi. Adekvatno korporativno upravljanje trebalo bi da obezbedi odgovarajući podsticaj upravnom odboru i menadžmentu da se fokusiraju na ciljeve koji su u interesu kompanije i njenih akcionara i treba da omogući efektivno praćenje performansi kompanije. Postojanje odgovarajućeg sistema korporativnog upravljanja, unutra pojedinačnih kompanija i u privredi kao celini, pomaže da se obezbedi određeni nivo poverenja koje je neophodno da bi tržišna ekonomija funkcionisala na odgovarajući način. Kao posledica, smanjuju se troškovi kapitala, a preduzeća su ohrabrena da efikasnije koriste resure, čime se postavljaju temelji razvoja. 
Korporativno upravljanje je samo jedan deo većeg ekonomskog konteksta u kojem preduzeća posluju, a koje obuhvata, na primer, makroekonomske politike i određen stepen konkurencije na tržištu proizvoda i faktora. Okvir korporativnog upravljanja takođe zavisi od zakonskog, regulatornog i institucionalnog okruženja.

Svaki rad koji ima opredmećenje dobija tržišno pozicioniranje, tako i intelektualni rad menadžera. Da li se taj rad plaća kao posebna deo u osnosu na deo konkretnog rada postavlja se pitanje. U ovim uslovima koje mi posmatramo možemo reći da se isključivo od profitne strukture preduzeća kreću i zarade menadžera. Ovo se može videti iz Tabele 1.

Tabela 1. Godišnje zarade menadžera u Nemačkoj

\begin{tabular}{|c|c|c|c|c|}
\hline Kompanija & Menadžer & $\begin{array}{c}\text { Fiksna } \\
\text { zarada }\end{array}$ & $\begin{array}{c}\text { Ukupna } \\
\text { zarada }\end{array}$ & $\begin{array}{c}\text { Zarada } \\
\text { celog UO }\end{array}$ \\
\hline Folksvagen & $\begin{array}{c}\text { Martin } \\
\text { Vinterkorn }\end{array}$ & $1.791,900$ & $16.596,200$ & $67.351,500$ \\
\hline Dajmler & Diter Ceče & $2.008,000$ & $8.813,000$ & $28.994,000$ \\
\hline Simens & Peter Lešer & $2.000,000$ & $8.652,200$ & $39.251,000$ \\
\hline Linde & Volgan Rajcle & $1.960,000$ & $6.852,500$ & $14.785,200$ \\
\hline Djče banka & Jozef Akerman & $1.650,000$ & $6.474,500$ & $27.323,700$ \\
\hline PWE & $\begin{array}{c}\text { Jirgen } \\
\text { Grosman }\end{array}$ & $2.700,000$ & $6.443,000$ & $16.218,000$ \\
\hline BMV & $\begin{array}{c}\text { Norbert } \\
\text { Janhofer }\end{array}$ & $1.020,000$ & $6.156,600$ & $27.249,100$ \\
\hline Adidas & Herbet Hajner & $1.400,000$ & $5.967,000$ & $14.791,000$ \\
\hline SAP & Jim Hageman & $1.150,000$ & $5.478,800$ & $24.182,200$ \\
\hline $\begin{array}{c}\text { Nemačka } \\
\text { pošta }\end{array}$ & Frank Apel & $1.745,000$ & $5.254,800$ & $21.322,300$ \\
\hline
\end{tabular}

Izvor: http://www.politika.rs/rubrike/Ekonomija/Zarade-nemackih-vrhunskih-menadzera-nisu-tajna.It.html

Iz navedenog zaključujemo da intelektualna svojina menadžera opredmećena kroz korporativno upravljanje nameće cenu kroz profitni bilans.

Taj okvir bi trebalo da obezbedi da se sva opipljiva pitanja u vezi sa kompanijom pravovremeno i tačno obavljuju, uključujući i finansijsku situaciju, poslovne performanse, vlasničku strukturu i upravljanje kompanijom. Osim toga, faktori kao što su poslovna etika i korporativna svest o interesima zajednica u kojima kompanija obavlja poslovanje u vezi sa društvenim okruženjem i životnom sredinom takođe mogu da utiču na reputaciju kompanije i njen drugoročan uspeh.

Svest o korporativnom upravljanju i njegovoj ulozi u globalnoj privredi neprekidno i stabilno raste u poslednjih nekoliko godina. U razvijenim privredama, u kojima aktivna tržišta za korporativnu kontrolu i raslojene vlasničke strukture otežavaju akcionarima da nadgledaju menadžment, aktivisti koji su i akcionari sve češće postavljaju pitanja u vezi sa upravljanjem, a prakse upravljanja kompanijama obično redovno i budno prati šira javnost. Korporativni neuspesi istaknutih kompanija u Sjedinjenim Američkim Državama i Evropi koji su se odvijali u poslednje vreme za posledicu imaju to da se sve veća pažnja obraća na korporativno upravljanje kao samostalan faktor rizika na razvijenim tržištima. Na tržištima u usponu, finansijske krize koje su pogodile Rusiju i istočnu Aziju krajem devedesetih godina XX veka takođe su otkrile velike praznine i nedostatke u praksama korporativnog upravljanja.

Berze i regulatorna tela širom sveta sve više naginju ka tome da se postave standardi ili kodeksi najboljih praksi korporativnog upravljanja. Investitori su počeli sistematičnije da proveravaju kakve su prakse korporativnog upravljanja u kompaniji kao sastavni deo procesa odlučivanja. Sve češće se rasprava o korporativnom upravljanju proteže van granica akcionara kompanije i njome se obuhvataju i ostali stejkholderi, kao što su kreditori, kupci, stručnjaci za zaštitu životne sredine i lokalne zajednice.

Loše prakse korporativnog upravljanja i poslovni neuspesi usko su povezani sa lošim finansijskim izveštavanjem i objavljivanjem korporativnih podataka. To utiče na poverenje investitora u finansijske informacije, što uzrokuje veće troškove kapitala. Da bismo potpunije razumeli razloge gubitka kredibiliteta i da bismo utvrdili mere koje je moguće preduzeti, proučićemo uloge koje imaju različiti učesnici u procesu finansijskog izveštavanja. Doći ćemo do zaključka da je osnov bilo koje strukture korporativnog upravljanja objavljivanje pouzdanih i verodostojnih finansijskih informacija (Kothari i Barone, 2012).

Većina velikih kompanija u Americi su javne kompanije sa širokom disperzijom vlasništva. Svaki akcionar poseduje samo mali deo akcija i ima mali uticaj na način rukovođenja kompanijom. Ako se akcionarima ne sviđa politika koju vodi uprava, mogu pokušati izglasati drugi upravni odbor koji će promeniti politiku rukovođenja. Ali takvi pokušaji su retko kad uspešni, a najjednostavnije rešenje za akcionare je prodaja akcija.

Razdvajanje vlasništva i uprave u velikim američkim kompanijama stvara potencijalni sukob interesa između akcionara i menadžera. Postoji nekoliko mehanizama razvijenih u svrhu smanjenja tog sukoba: 
- Akcionari biraju upravni odbor, koji onda imenuje menadžere, nadgleda in i u zavisnosti od prilika, otpušta in.

- Plata menadžera je vezana za njihov rezultat na poslu.

- Novi tim preuzima kompanije koje slabo posluju i zamenjuje upravu.

Ovi mehanizmi funkcionišu samo ako je sve transparentno, tako da se lako može uočiti koliko dobro kompanija posluje. Nažalost, nepošteni menadžeri s primamljivim paketima opcija mogu nastojati sakrit istinu od investitora. Kad investitori na kraju saznaju pravo stanje stvari, već su u velikoj nevolji.

Tako su razni skandali naveli Kongres SAD da usvoji Zakon Sarbejns-Oksli, kojim je propisano da kompanije i njihove računovođe dostavljaju direktorima, poveriocima i akcionarima informaciju koja im je potrebna za praćenje napretka. Između ostalog, zakonom je određen nadzorni odbor za praćenje računovodstva javnih kompanija; revizorskim kompanijama je zabranjeno nuditi druge usluge kompanijama čije finansijske izveštaje revidiraju; zabranjeno je pojedincu voditi reviziju iste kompanije više od pet godina; a odbor direktora za reviziju se mora sastojati od direktora koji ne zavise od uprave kompanije. Sarbejns-Oksli takođe zahteva da uprava (1) potvrdi da finansijski izveštaji predstavljaju stvarni finansijski položaj kompanije i (2) pokaže da kompanija ima prikladnu kontrolu i sledi procedure za finansijsko izveštavanje. Sve to ima svoju cenu. Na primer, izvršni direktor kompanije Tenant (Tennant), srednje velikog proizvođača sredstava za čišćenje, procenio je da usklađivanje s tim zakonom vodi do udvostručavanja naknada za reviziju, što znači skoro dodatnih milion dolara troškova.

Vlasništvo i kontrola su obično odvojeni u američkim kompanijama, a veliki blok akcija može osigurati efektivnu kontrolu čak i kad ne postoji većinski vlasnik. Ipak, koncentracija vlasništva je manja nego u nekim drugim industrijalizovanim zemljama. Razlike nisu toliko očigledne u Kanadi, Britaniji, Australiji i drugim zemljama engleskog govornog područja, ali postoje dramatične razlike u Japanu i kontinentalnoj Evropi.

U Japanu su glavne industrijske i finansijske kompanije tradicionalno vezane uz grupe zvane keiretsu. Na primjer, Micubiši (Mitsubishi) keiretsu sastoji se od 29 kompanija, uključujući banku, dva osiguravajuća društva, proizvođača automobila, pivaru i čeličanu. Članovi keiretsu povezani su zajedno na nekoliko načina. Prvo, menadžeri mogu biti u upravnom odbori drugih kompanija u grupi, a ,,veće predsednika" izvršnih direktora redovno se sastaje. Drugo, svaka kompanija u grupi ima akcije u drugim kompanijama. I treće, kompanija obično posuđuje od keiretsu banke ili od druge kompanije iz grupe. Ta povezanost ima nekoliko prednosti. Kompanije mogu dobiti sredstva od drugih članova grupe, bez potrebe da otkriju poverljive podatke i ako član grupe upadne u finansijske nevolje, problemi se rešavaju u grupi, a ne ide se odmah pred stečajni sud.

Stabilna i koncentrisana baza akcionara u velikim japanskim korporacijama olakšava im da se odupru pritisku kratkoročnih performansi i omogućava im da se usredsrede na stvaranje dugoročne prednosti. Ali japanski sistem vođstva korporacijam ima i svojih mana, budući da nedostatak tržišne discipline može promovisati suviše lagodan život i omogućiti neprofinim kompanijama da odlože sprovođenje neophodnih mera. Kako je japanska privreda tokom 1990-ih oslabila, te slabe strane su postale još uošljivije, a veze koje su povezivale grupe keiretsu počele su slabiti i kompanije su počele prodavati akcije drugim članovima grupe.

Keiretsu postoje samo u Japanu. Ali velike kompanije u kontinentalnoj Evropi povezane su na sličan način. Na primer, banke i druge kompanije često poseduju ili kontrolišu velike blokove akcija i mogu insisitrati na promenama u upravi ili strategijama kod loše vođenih kompanija. Na taj način su nadzor i kontrola povereni u velikoj meri bankama i drugim kompanijama.

\section{ZAKLJUČAK}

Ključne komponente modernog profesionalnog sistema menadžmenta u korporacijama razvijene tržišne ekonomije su:

- odvajanje menadžmenta od vlasništva,

- profesionalizacija menadžerske funkcije i menadžerskih organa,

- uspostavljanje menadžerskih standarda učinka,

- merenje i ocenjivanje uspešnosti menadžera u poslovanju,

- nagrađivanje uspešnih i kažnjavanje neuspešnih menadžera i

- zaključivanje profesionalnih menadžerskih ugovora.

U nizu faktora koji su doprineli aktuelnosti korporacijskog upravljanja značajno mesto pripada procesu privatizacije, a samim tim i iznalaženju mogućnosti za unapređenje, kako poslovanja tako i odlučivanja u privatizovanom preduzeću. Sledeći faktor je talas integracija (spajanja i pripajanja, odnosno preuzimanja) korporacija tokom 1980-ih u SAD i 1990-ih u Evropi, odnosno globalnih integracija (internacionalnih i interkontinentalnih) krajem XX veka, koji je pokazao da su mnoge kompanije bile „uspavane“, odnosno nedovoljno dobro vođene, pa su tako postale plen akcije neprijateljskog preuzimanja. Na način upravljanja korporacijama u mnogome je uticalo i povećanje značaja institucionalnih investitora, a posebno penzionih fondova. Kao jedan od faktora može se istaći $\mathrm{i}$ 
globalizacija finansijskog tržišta kapitala uključujući i njegovu deregulaciju, a posebno u Evropi. Niz kriza i skandala koji su se desili (azijska 1997. godine, ruska 1998. godine i kao i bankroti i skandali u SAD 2001. i 2002. godine) bili su nesumnjivo rezultat slabosti korporativnog upravljanja.

Unapređenje korporacijskog upravljanja danas se nameće kao neminovnost. Ono bi trebalo, između ostalog, da da značajan doprinos i povećanju ekonomske efikasnosti i tržišnog privređivanja, a naravno ono mora da uvažava pravno okruženje, kulturni ambijent, tradiciju, vlasništvo, kao i druge strukturne razlike.

$\mathrm{U}$ praksi ne postoji jedinstven model dobrog korporativnog upravljanja i zaštite intelektualne svojine menadžera. Različitost pravnih sastava, institucionalnih okvira i tradicija, dovela je do toga da se u svetu razvio celi spektar različitih pristupa. Međutim, zajedničko svim dobrim režimima korportivnog upravljanja jeste da visoki prioritet daju interesima akcionara, koji korporaciji poklanjaju poverenje da će njihova sredstva koristiti mudro i efikasno. u okruženju.

Principi korporativnog upravljanja su evolutivni i treba ih posmatrati u pogledu značajnih promena

\section{LITERATURA}

1. Babić V., Korporativno upravljanje u uslovima tranzicije, Ekonomski fakultet, Kragujevac, 2004.

2. Đorđević, D, Bešić H, C, Sajfert,N Z, Leksikon Menadžmenta, Agencija Matić, Beograd, 2006.

3. Jovičić, J, Mirosavić, S, Međunarodni ekonomski odnosi, NUBL Banja Luka, 2012.

4. Jovičić M, Stavrić, B, Menadžment, Fakultet poslovne ekonomije Bijeljina, 2009.

5. Kothari, J, Barone, E, Finansijsko računovodstvo: Međunarodni pristup, Data status Beograd, 2012.

6. Mihajlović M, Dašić M., Menadžment znanja kao faktor povećanja efikasnosti organizacije, ODITOR, Centar za ekonomska i finansijska istraživanja, Beograd, 09/2009, str. 33-36.

7. Miletić A., Rstić M., Lutovac M., Patent kao instrument zaštite inovacija u cilju dugoročnog rasta organizacije, Tehnika, Savez inžinjera i tehničara Srbije, Beograd, 02/2014, str. 309-3016.

8. Sofronijević A., Milićević V., llić B., Savremeni menadzment i promene vezane za automatizaciju intelektualnih poslova, Tehnika, Savez inžinjera i tehničara Srbije, Beograd, 03/2013, str. 533538.

\section{Abstract}

The development of more complex forms of organization of the company is to create the conditions of a small number of complex economic, but also organizationally complex and komlikovanijih corporate organizations whose successful conduct of the owners often did not have enough resources, so they hired a professional and competent teams of experts who are trusted with the management of such organizations. In exercising the power of new ideas and concepts based on knowledge, managers in corporations are becoming an indispensable element of every company will be able to change, adapt and create new opportunities to compete successfully in a changing business environment. However, the transfer of responsibility for the management of the corporation managers has resulted in the emergence of abuse of senior management positions in order to realize their own interests. The main objective of this paper is to show how unlike traditional enterprise, today we have a situation in which such property owners corporation is a conceptual and thoughtful decision managers, which should represent the members of their intellectual property.

Key words: corporate management, process management, intellectual property, company

Rad primljen: 30.09.2015.

Rad prihvaćen: 15.02.2016. 